\title{
DIETARY PHYTOCHEMICALS IN CELL CYCLE ARREST AND APOPTOSIS - AN INSIGHT
}

\author{
Sapra $R^{1}$, Gupta $V^{2}$, Bansal $R^{3}$, Bansal $P^{1^{*}}$ \\ ${ }^{1}$ Dept. of Biochemistry, PGIMER, Chandigarh, INDIA \\ ${ }^{2}$ University Center of Excellence in Research, BFUHS, Faridkot, INDIA \\ ${ }^{3}$ Dept of Microbiology, GGSMCH, BFUHS, Faridkot, INDIA
}

*Corresponding Author's Email ID: bansal66@yahoo.com, vikas_4308@rediffmail.com

Received 28 Jan 2012; Revised 03 March 2012; Accepted 03 March 2012, Available online 15 March 2012

\begin{abstract}
Recently chemoprevention by the use of naturally occurring dietary substances is considered as a practical approach to reduce the ever-increasing incidence of cancer. While a number of natural foods, fruit and vegetables are recommended for prevention of cancer and other diseases, their active ingredients and their mechanism of action are not well understood. A number of dietary phytochemicals are under phase III clinical trial due to their potent therapeutic effect against cancer. Moreover most of the drugs being used in chemotherapy have been derived from plant products. With an advanced knowled ge of molecular science and refinement in isolation and structure elucidation techniques, world is in a much better position to identify various anticancer herbs and develop therapeutic agents for cancer. However lack of success with targeted mono-therapy and multi-drug resistance to existing chemotherapeutic agents has forced scientists to practice either combination therapy or use a number of agents working at different sites to get some synergistic effect. Since most of the cells do not show resist ance to natural plant products; hence the use of natural plant products can be an alternative modality of treatment for multidrug resistant tumors. In this review article an attempt has been made to put some known phytochemicals of dietary origin that act at various stages of cell cycle and/or apoptotic pathway at a single platform, so that by understanding the synergistic, additive or antagonistic interactions of various constituents of anticancer herbs, the herbal regimens can be designed to fight cancer.
\end{abstract}

Keywords: Apoptosis, cell cycle arrest, vegetables, spices, fruits.

\section{INTRODUCTION}

Cancer may be defined as uncontrolled tissue growth that results from an imbalance between cell division and apoptosis ${ }^{1}$. It is a dynamic process that involves many complex factors, which may explain why a "magic bullet" cure for cancer has not been found. In spite of the significant progress in the development of anticancer therapies the incidence of cancer is still on its rise worldwide. The existing treatment modules include chemotherapy, radiotherapy and surgery with a limited role in eradication of the disease. Multidisciplinary scientific investigations and approaches are making best efforts to fight this disease, but the adequate cure is yet to be brought into world medicine. So cancer patients who already got crippled with this disease followed by burden of drug induced toxic side effects have now turned to seek help from complimentary and alternative medicine hoping for the cure. Thus an alternative measure to the existing western medicine and some of its unavoidable side effects is the use of medicinal plant products to arrest this dangerous disease.

Natural products such as phytochemicals have been placed on the top of the pyramid in chemoprevention ${ }^{2}$. Various studies indicate that phytochemicals can modulate the complex multistage process of carcinogenesis ${ }^{3}$. Based on reports regarding anticancer activity of natural products National Cancer Institute has been cited to identify about 40 edible plants possessing potential chemopreventive compounds known as phytochemicals in global language ${ }^{4-5}$. Although chemopreventive effect of these dietary phytochemicals is initially based on cell line culture, in vitro and animal model studies, yet many of them are at the verge of crossing phase III clinical trials ${ }^{6-7}$. It is well known that human being is consuming vegetarian diet for the last thousands of years. In day to day life every body is ingesting a cocktail of thousands of phytochemicals in the form of vegetables, fruits, spices and other food additives however most of the population is unaware about its biochemical, physiological and pharmacological therapeutic inputs. Recently chemoprevention by the use of naturally occurring dietary substances is considered as a practical approach to reduce the ever-increasing incidence of cancer. This measure for cancer control is based on the presumption that as cancer develops through a multi-step process, each step may be an eventual target for reversing or suppressing the process. Thus, the design and development of chemopreventive agents that act on specific and/or multiple molecular and cellu lar targets is gaining support as a rational and potential approach to prevent and control cancer. So the interference of multistage carcinogenesis by modulating intracellular signaling pathways may provide molecular basis of chemoprevention with a wide variety of phytochemicals of dietary origin. It has been estimated that about 25000 different chemical compounds occur in fruits, vegetables and other plants eaten by man. As of 2002 more than 500 of these compounds have been shown to be identified as potential modifiers of cancer process ${ }^{8}$. According to a survey out of 121 prescription drugs in use for cancer treatment, 90 have been derived from plant species and $74 \%$ of these drugs were discovered by pursuing studies on a folklore claim $^{9-10}$. 
Table 1: Dietary phytochemicals from spices with site of their action in cell cycle or apoptosis

\begin{tabular}{|c|c|c|c|c|}
\hline Dietary source & $\begin{array}{l}\text { Active } \\
\text { component }\end{array}$ & $\begin{array}{l}\text { Site of action in cell cycle or } \\
\text { apoptotic path way }\end{array}$ & Result & Ref. \\
\hline $\begin{array}{l}\text { 1. Mulethi } \\
\text { (Glycerrhiza glabra) }\end{array}$ & $\begin{array}{l}\text { Glycyrrhetic acid, } \\
\text { Glycyrrhetin ic } \\
\text { acid, } \\
\text { Glycyrrhizin }\end{array}$ & $\begin{array}{l}\text { Inhibits the prolife ration, cytotoxic. Release of } \\
\text { cytochrome } \mathrm{C} \text { from mitochondria, activation of } \\
\text { caspases, Mitochondrial me mbrane potential, } \\
\text { Inhibit NF-kB activation pathway }\end{array}$ & Apoptosis & $30-31$ \\
\hline $\begin{array}{l}\text { 2. Heeng, (Ferula } \\
\text { asafoetida) }\end{array}$ & $\begin{array}{l}\text { Luteolin, } \\
\text { Fertinin, } \\
\text { ferutidin }\end{array}$ & $\begin{array}{l}\text { Sensitizes TRAIL induced apoptosis, Inhibit cell } \\
\text { proliferation at level of DNA synthesis (S- phase). }\end{array}$ & $\begin{array}{l}\text { Apoptosis/ } \\
\text { Cell cycle arrest }\end{array}$ & $32-35$ \\
\hline $\begin{array}{l}\text { 3. Ginger } \\
\text { (Zingiber officinale) }\end{array}$ & $\begin{array}{l}\text { Gingerol, } \\
\text { 6-shogaol }\end{array}$ & $\begin{array}{l}\text { Mitochondrial me mbrane potential, Release of } \\
\text { cytochrome } \mathrm{C} \text { from mitochondria, activation of } \\
\text { caspases, increase in Bax. }\end{array}$ & Apoptosis & $36-38$ \\
\hline $\begin{array}{l}\text { 4, Fennel } \\
\text { (Foeniculum vulgare) }\end{array}$ & Anethol & Inhibit NF-kB activation pathway & Apoptosis & 39 \\
\hline $\begin{array}{l}\text { 5. Turmeric } \\
\text { (Curcuma longa) }\end{array}$ & Curcumin & $\begin{array}{l}\text { Activation of caspases, TRAIL induction, Re lease } \\
\text { of cytochrome C from mitochondria, arrest G2M } \\
\text { phase, down regulates expres sion of cyclin D1, } \\
\text { upregulation of Cdk inhibitors }\end{array}$ & Apoptosis & $40-48$ \\
\hline $\begin{array}{l}\text { 6. Clove } \\
\text { (Syzigium aromaticum) }\end{array}$ & Eugenol & Activation of caspases -3 , down regulation of $\mathrm{Bcl}-2$ & Apoptosis & 49 \\
\hline $\begin{array}{l}\text { 7.Cardamom } \\
\text { (Elettarria } \\
\text { cardamomum) }\end{array}$ & Limonene & Inhibit NF-kB activation pathway & Apoptosis & 4 \\
\hline $\begin{array}{l}\text { 8. Coriander } \\
\text { (Coriandrum sativum) }\end{array}$ & Linalool & Inhibit NF-kB activation pathway & Apoptosis & 4 \\
\hline 9. Cinnamon & Polyphenols & G2M cell cycle arrest & Cell cycle arrest & 50 \\
\hline $\begin{array}{l}\text { 10.Grape seed } \\
\text { (Vitis vinifera) }\end{array}$ & Proanthocyanidins & $\begin{array}{l}\text { Release of cytochrome C from mitochondria, } \\
\text { Activation of caspases, Induction of Apaf-1, } \\
\text { change in } \mathrm{Bax} / \mathrm{Bc} 12 \text { ratio }\end{array}$ & Apoptosis & $51-54$ \\
\hline $\begin{array}{l}\text { 11.Red pe pper } \\
\text { (Capsicum annum) }\end{array}$ & Capsaicin & Mitochondrial me mbrane potential, caspases - 3 & Apoptosis & $55-57$ \\
\hline $\begin{array}{l}\text { 12. Black pe pper } \\
\text { (Piper nigrum) }\end{array}$ & Piperine & Inhibit NF-kB activation pathway & Apoptosis & 4 \\
\hline
\end{tabular}

According to an estimate, two-thirds of human cancers could be prevented by making modifications in the diet ${ }^{11}$. In 1997 , an international review panel of the World Cancer Research Fund's American Institute for Cancer Research (AICR) concluded from an exhaustive collection of worldwide research on this topic that "diets high in vegetables and fruits (more than $400 \mathrm{~g} / \mathrm{day}$ ) could prevent at least $20 \%$ of all cancer incidence" 12 . Recently, a greater emphas is has been given towards the researches on complementary and alternative medicine that deals with cancer management. According to a very recent report an epidemiological survey describes the efficacy of relationship between fruit and vegetable consumption and cancer prevention. Available data suggests that it is not presently clear that cancer is among the diseases prevented by fruits and vegetable however consumption of a diet rich in vegetables and fruits has been shown to be one of the best approaches to improve health and reduce chronic disease ${ }^{13}$.

Herbal medicines have a vital role in the prevention and treatment of cancer. Several studies have been conducted on herbs under a multitude of ethno botanical grounds. For example, Hartwe $11^{14-22}$ has collected data on about 3000 plants, those of which possess anticancer properties and have been used as potent anticancer drugs ${ }^{23}$. Advances in pharmaceutical research in countries like USA, Germany, France, Japan, and China has been shown to considerably improve quality of herbal medicines used in the treatment of cancer. This review intends to focus on some of the components of daily diet which is inadvertently provided with a number of active constituents that have been shown to work on different target sites for anticancer activity. 
The purpose of this communication is to put all the commonly used dietary components of potential and value in anticancer activity so that researchers may further put efforts in designing drugs which may partially explain the effectiveness of selected food factors as chemopreventive agents.

Table 2: Dietary phytochemicals from fruits with site of their action in cell cycle or apoptosis

\begin{tabular}{|c|c|c|c|c|}
\hline Dietary source & $\begin{array}{l}\text { Active } \\
\text { component }\end{array}$ & Site of action in cell cycle or apoptotic pathway & Result & Ref \\
\hline $\begin{array}{l}\text { 1. Grape, } \\
\text { (Vitis vinifera) } \\
\text { wine }\end{array}$ & Resveratrol & $\begin{array}{l}\text { Release of cytochrome C from mitochondria, } \\
\text { activation of caspases, decrease in survivin, increase } \\
\text { in smac/DIABLO, sensitizes TRAIL induced } \\
\text { apoptosis, down regulation of cyclin D1/Cdk4 } \\
\text { complex, G2 arrest through Cdk7 and Cdc } 2 \text { kinases, } \\
\text { G1 arrest, S phase arrest }\end{array}$ & $\begin{array}{l}\text { Apoptosis/ Cell } \\
\text { cycle arrest }\end{array}$ & $58-69$ \\
\hline $\begin{array}{l}\text { 2. Citrus fruits } \\
\text { (Citrus limon, C. } \\
\text { paradis, C retirulatai) }\end{array}$ & Limonene & $\begin{array}{l}\text { Inhibits growth of cancer, Inhibit NF-kB activation } \\
\text { pathway }\end{array}$ & $\begin{array}{l}\text { Cell cycle arrest } \\
\text { /Apoptosis }\end{array}$ & 4 \\
\hline $\begin{array}{l}\text { 3. Himalayan may } \\
\text { apple } \quad \text { (Podophylum } \\
\text { peltatum) }\end{array}$ & Podophyllin & Inhibit mitotic spindle in metaphase & Cell cycle arrest & 4 \\
\hline $\begin{array}{l}\text { 4.Pineapple } \\
(\text { Ananas comosus) }\end{array}$ & Brome lain & $\begin{array}{l}\text { Enhance cytotoxic activity of monocytes and } \\
\text { macrophages }\end{array}$ & Cytotoxic & 4 \\
\hline $\begin{array}{l}\text { 5. Mango } \\
\text { (Mangifera indica) }\end{array}$ & lupeol & $\begin{array}{l}\text { Activation of caspases, enhance the expression of } \\
\text { Fas receptor and FADD protein }\end{array}$ & Apoptosis & 70 \\
\hline $\begin{array}{l}\text { 6. Pomegranate } \\
\text { (Punica granatum), } \\
\text { Strawberry. }\end{array}$ & $\begin{array}{l}\text { Anthocyanin/ } \\
\text { Delphinidin }\end{array}$ & $\begin{array}{l}\text { Nuclear condensation, DNA frag mentation, } \\
\text { Mitochondrial membrane potential changes, } \\
\text { Activation of caspases, Release of cytochrome C } \\
\text { from mitochondria }\end{array}$ & Apoptosis & $71-11$ \\
\hline $\begin{array}{l}\text { 7. Almond } \\
\text { (Prunus dulcis) }\end{array}$ & Morin & Inhibit NF-kB activation pathway & Apoptosis & 78 \\
\hline $\begin{array}{l}\text { 8.Guava } \\
\text { (Psidium guajava) }\end{array}$ & Gallic acid & Inhibit NF-kB activation pathway & Apoptosis & 4 \\
\hline $\begin{array}{l}\text { 9.Black Ras pberries } \\
\text { (Rubus occidentalis) }\end{array}$ & $\begin{array}{l}\text { Cynidin } \\
\text { glycosides }\end{array}$ & Antiprolife rative activity & Apoptosis & $79-83$ \\
\hline $\begin{array}{l}\text { 10. Mulberry } \\
\text { Morus sps. }\end{array}$ & Sanggenon- C & Inhibit NF-kB activation pathway & Apoptosis & 4 \\
\hline
\end{tabular}

\section{MECHANIS M OF ACTION}

Programmed cell death has received phenomenal attention in the past few years. Apoptosis was coined to describe programmed cell death, a process involved in cell death involved in cellular development and aging distinct from necrosis. Apoptotic cells die by design whereas necrotic cells die by accidental and lethal injury ${ }^{24}$. Apoptosis can be divided into three non-distinct phases: an induction phase, an effector phase, and a degradation phase. The induction phase depends on death inducing signals to stimulate pro-apoptotic signal transduction cascades. These death-inducing signals include reactive oxygen species, Ceramide signaling, over activation of $\mathrm{Ca}^{+2}$ pathways, and Bcl-2 family proteins such as Bax and Bad. In phase two, the effector phase, the cell becomes committed to die by the action of a key regulator, which is the mitochondrion. The last phase, a degradation phase, involves both cytoplasmic and nuclear events. In the cytoplasm, a complex cascade of protein cleaving enzymes called caspases is activated. In the nucleus the chromatin condenses, the nuclear envelop breaks down, and the DNA fragments. Finally the cell is frag mented into apoptotic bodies, phosphatidyl serine on the me mbranes is recognized, and apoptotic bodies are phagocytosed by surrounding cells or macrophages ${ }^{24-25}$. Apoptosis also involves characteristics changes within the nucleus. Endonucleas es are activated and begin to degrade the nuclear DNA. In so me cell types, DNA is degraded into fragments the size of oligonucleosomes, whereas in others larger DNA frag ments are produced. So the search for therapeutic agents targeting cellular apoptotic components is regarded as a promising feature in the therapeutic treatment of a wide variety of diseases ${ }^{26}$. It is now known that mitochondria play a central regulatory role in apoptosis, particularly through cytochrome $\mathrm{C}$ pathway. Mitochondria and radical species are intimately involved in the apoptosis. Increased oxidative stress 
from ROS and RNS changes the cellular redox potentials, depletes glutathione, and decreases reducing equivalents like NADP and NADPH. These intracellular changes are sufficient to induce the formation of mitochondrial permeability transition pores, leading to the subsequent release of cytochrome $\mathrm{c}$ and the activation of the caspases cascade.

Table 3: Dietary phytochemicals from vegetables with site of their action in cell cycle or apoptosis

\begin{tabular}{|c|c|c|c|c|}
\hline Dietary source & $\begin{array}{l}\text { Active } \\
\text { component }\end{array}$ & Site of action in cell cycle or apoptotic pathway & Result & Ref \\
\hline $\begin{array}{l}1 . \quad \text { Crucifer ous } \\
\text { vegetables } \\
\text { Brrasica oleracea, } \\
\text { Brassica campestris }\end{array}$ & $\begin{array}{l}\text { Brassinin, } \\
\text { Is othicyanates, } \\
\text { sulphoraphane }\end{array}$ & Activation of caspases, effect on p53, & Apoptosis & $84-88$ \\
\hline $\begin{array}{l}\text { 2. Karela } \\
\text { (Momordica } \\
\text { charantia) }\end{array}$ & $\begin{array}{l}\text { Momorcharaside } \\
\text { B }\end{array}$ & Inhibited DNA and RNA synthesis & Cell cycle arrest & 4 \\
\hline $\begin{array}{l}\text { 3.Pea seeds } \\
\text { (Pisum sativum) }\end{array}$ & $\begin{array}{l}\text { Metaxylo- } \\
\text { hydroquinone }\end{array}$ & Antimitotic effect, depoly merise DNA & $\begin{array}{l}\text { Cell cycle } \\
\text { arrest/ } \\
\text { Apoptosis }\end{array}$ & 4 \\
\hline $\begin{array}{l}\text { 4.Garlic } \\
\text { (Allium sativum), } \\
\text { Onion (Allium cepa) }\end{array}$ & $\begin{array}{l}\text { Ajoein, Allicin, } \\
\text { Alliumin, Allixin } \\
\text { Organo-sulphur } \\
\text { compounds }\end{array}$ & $\begin{array}{l}\text { Activation of caspases, Release of cytochrome } \mathrm{C} \\
\text { from mitochondria, effect on p53, activation of } \mathrm{Bax} \\
\text { and down regulation of } \mathrm{Bcl}-2\end{array}$ & Apoptosis & $89-92$ \\
\hline $\begin{array}{l}\text { 5., Artichoke } \\
\text { (Silybum marianum) }\end{array}$ & $\begin{array}{l}\text { Sily marin, } \\
\text { Silibinin }\end{array}$ & $\begin{array}{l}\text { Release of cytochrome C from mitochondria, } \\
\text { Activation of caspases, Increase of p53, } \\
\text { Mitochondrial membrane potential changes, G1 cell } \\
\text { cycle arrest, G2/M arrest }\end{array}$ & $\begin{array}{l}\text { Apoptosis /cell } \\
\text { cycle arrest }\end{array}$ & 93-98 \\
\hline 6. Lettuce & Apigenin & Activation of caspases, G2M arrest & $\begin{array}{l}\text { Apoptosis /cell } \\
\text { cycle arrest }\end{array}$ & प्र-101 \\
\hline $\begin{array}{l}\text { 7. Soyabean } \\
\text { (Pueraria labata) }\end{array}$ & $\begin{array}{l}\text { Genistein, } \\
\text { diadezine }\end{array}$ & $\begin{array}{l}\text { Mitochondrial me mbrane potential changes, Release } \\
\text { of cytochrome C from mitochondria, PARP } \\
\text { cleavage, } \\
\text { Activation of caspases, down regulation of } \mathrm{Bcl}-2 \text {, } \\
\text { G2M cell cycle arrest, }\end{array}$ & $\begin{array}{l}\text { Cell cycle arrest } \\
\text { /Apoptosis }\end{array}$ & $102-104$ \\
\hline $\begin{array}{l}\text { 8. Tomato } \\
\text { (Lycopersicum } \\
\text { esculentum) }\end{array}$ & $\begin{array}{l}\text { Lycopene } \\
\text { Lutein }\end{array}$ & $\begin{array}{l}\text { Release of cytochrome } \mathrm{C} \text { from mitochondria, } \\
\text { activation of caspases, effect on p53, increase in } \\
\text { Bax. }\end{array}$ & Apoptosis & $103-108$ \\
\hline $\begin{array}{l}\text { 9. Carrots } \\
\text { (Daucus carota) }\end{array}$ & $\begin{array}{l}\text { Beta carotenes, } \\
\text { Trans as arone }\end{array}$ & $\begin{array}{l}\text { Mitochondrial membrane potential, Inhibit NF-kB } \\
\text { activation pathway }\end{array}$ & Apoptosis & $708-109$ \\
\hline 10.Aloe vera & $\begin{array}{l}\text { Acemannan, } \\
\text { Emodin }\end{array}$ & $\begin{array}{l}\text { Enhances activity of immune cells against cancer, } \\
\text { induces growth inhibition, Inhib it NF-kB activation } \\
\text { pathway }\end{array}$ & $\begin{array}{l}\text { Cell cycle arrest } \\
\text { Apoptosis }\end{array}$ & 110 \\
\hline $\begin{array}{l}\text { 11.Chickpea } \\
\text { (Cicer arietinum) }\end{array}$ & Genistein, & Inhibit NF-kB activation pathway & Apoptosis & 4 \\
\hline
\end{tabular}

Most cells regenerate to replace dead or damaged cells or to grow. For this process the cell doubles its DNA content that forms two sets of chromosomes that line up on spindles within the cell before the cell divides into two equal halves through cell cycle. The cell cycle can be divided into three identifiable components known as $\mathrm{G}_{0} \mathrm{G}_{1}, \mathrm{~S}$ and $\mathrm{G}_{2} \mathrm{M}$ phase.
$\mathrm{G}_{0}$ is the phase where cells are quiescent and not taking part in the cell division. $G_{1}$ is the phase where cell is gearing up to move through cell division. S-phase is that part of cell cycle where synthesis of DNA occurs and where DNA staining increases. $G_{2}$ and $M$ phases of cycle are where $4 n$ DNA is present, just prior to and during mitosis, 
respectively. Several proteins are known to monitor and regulate the timings of the events in the cell cycle. Cyclins and cyclin dependent kinases constitute the major switches in control panel. Out of a number of checkpoints in the cell cycle the $G_{1} / S$ phase transition constitutes an important regulatory point. In G1 phase various complex signals interact to decide a cell's fate i.e. proliferation, quiescence, differentiation, or apoptosis. This phase is mainly characterized by gene expression and the synthesis of all proteins necessary for DNA replication in a cell thus making this part of cell cycle highly sensitive and responsive to various exogenous stimuli like therapies. So, tumorigenesis is associated with the overexpression of growth promoting cell cycle factors as well as the dysregulation of the cell cycle check points ${ }^{27}$.

From a wider perspective plant based compounds continue to play an essential role in the primary health care of $80 \%$ of world's population ${ }^{28}$. Currently over $60 \%$ of anticancer agents in use are derived from natural sources ${ }^{29}$. Three major types of plant derived chemopreventive agents include inhibitors of carcinogen formation, blockers of carcinogen interaction with it's target sites and suppressor of tumor production. So the dietary components can regulate apoptosis or cell division by working at various points of pathways mentioned in Table.1 - 4 .

Table 4: Dietary phytochemicals from miscellaneous foods with site of their action in cell cycle or apoptosis

\begin{tabular}{|c|c|c|c|c|}
\hline Dietary source & $\begin{array}{l}\text { Active } \\
\text { component }\end{array}$ & Site of action in cell cycle or apoptotic pathway & Result & Ref \\
\hline $\begin{array}{l}\text { 1.Tulasi } \\
\text { (Ocimum sanctum) }\end{array}$ & Orientin, Vicen in & $\begin{array}{l}\text { DNA frag mentation, } \\
\text { Shrunken cytoplasm, }\end{array}$ & Apoptosis & |ाIनाIL \\
\hline $\begin{array}{l}\text { 2.Black tea } \\
\text { (Camelia sinensis) }\end{array}$ & Theaflavins & $\begin{array}{l}\text { Inhibit matrix metallo proteinases, Inhibit NF-kB } \\
\text { activation pathway }\end{array}$ & Apoptosis & $713-116$ \\
\hline $\begin{array}{l}\text { 3. Green tea } \\
\text { (Camelia sinensis) }\end{array}$ & $\begin{array}{l}\text { Epigallocatechin } \\
\text { gallate }\end{array}$ & $\begin{array}{l}\text { Activates TRAIL induced apoptosis, activation of Fas, } \\
\text { inhibition of } \mathrm{Bcl} 2 \text {, Mitochondrial me mbrane potential }\end{array}$ & Apoptosis & $117-129$ \\
\hline $\begin{array}{l}\text { 4. Food colouring } \\
\text { agent } \\
\text { indica) }\end{array}$ & Garcinol & $\begin{array}{l}\text { Release of cytochrome } \mathrm{C} \text { from mitochondria, } \\
\text { Activation of caspases, }\end{array}$ & Apoptosis & TSO-IST \\
\hline $\begin{array}{l}\text { 5. Coffee } \\
\text { (Theobroma cacao) }\end{array}$ & Caffeine & Changes in p53, Inhib it NF-kB activation pathway & Apoptosis & $132-136$ \\
\hline 6.Oli ve oil & $\begin{array}{l}\text { Secoiridoid } \\
\text { Tyrosol der. }\end{array}$ & Inhibit cell proliferation & $\begin{array}{l}\text { Cell cycle } \\
\text { arrest } \\
\text { /Apoptosis }\end{array}$ & $137-140$ \\
\hline $\begin{array}{l}\text { 7. Honey } \\
\text { (Apis mellifera) }\end{array}$ & Caffeic acid & Activation of caspases and Fas, Induction of p53, & Apoptos is & 141 \\
\hline
\end{tabular}

\section{CONCLUS IONS}

Although only a few numbers of these phytochemicals have been selected for human phase III trials, yet other available friendly phytochemicals has not been discarded. A significant number of evidences suggest that an increased consumption of fruit and vegetables is a relatively easy and practical strategy to reduce incidence of cancer. Although a number of compounds that constitute food differ physically, chemically, biochemically, physiologically or pharmacologically yet they are subjected to additive, synergistic, cumulative or antagonistic effect that cannot be simply reproduced in a pill. At the same time because the length of chemopreventive treatments require the administration of low doses of chemopreventive agents to avoid toxic effects, daily diet seems to be the appropriate option. This will also provide a better patient compliance as compared to any new agent. So paradoxically or scientifically still most effective chemopreventive regimen is diet that also supports 2500 years old famous saying of Hippocrates " Let food be thy medicine and let medicine be thy food". 


\section{REFRENCES}

1. Bsoul SA, Huber MA, Terezhalmy GT, Squamous cell carcinoma of the oral tissues: A comprehensive review for oral healthcare providers, Jour Contemp Dent Pract, 2005 , 4(6), 1-16.

2. Croce CM, How can we prevent cancer? Proc Natl Acad Sci USA, 2001, 98, 10986-10988.

3. Bode AM, Dong Z, Targeting signal transduction pathways by chemopreventive agents, Mutation Research/Fundamental and Molecular Mechanisms of Mutagenesis, 2004, 555(1-2), 33-51.

4. Aggarwal BB, Shishodia S, Molecular targets of dietary agents for prevention and therapy of cancer, Biochem Pharmacol, 2006, 71, 1397-1421.

5. Surh YJ, Cancer chemoprevention with dietary phytochemicals, Nat. Rev. Cancer, 2003, 3, 768-780.

6. Greenwald P, Cancer chemoprevention, BMJ, 2004, 324, 714-718.

7. Russo GL, Ins and outs of dietary phytochemicals in cancer chemoprevention, Biochem Pharmacol, 2007, 74, 533-544.

8. Milner JA, Functional foods and health: a US perspective, Br J Nutr, 2002, 88(2), S151-S158.

9. Craig WJ, Phytochemicals: guardians of our health, J Am Diet Assoc, 1997, 97, S199-204.

10. Craig WJ, Health-promoting properties of common herbs, Am J Clin Nutr, 1999, 70, S491-499.

11. Sarkar FH, Yiwei Li, Cell signaling pathways altered by natural chemopreventive agents, Mutation Research/Fundamental and Molecular Mechanisms of Mutagenesis, 2004, 555(1-2), 53-64.

12. World Cancer Research Fund's, American Institute for Cancer Research (AICR), Food, Nutrition and the Prevention of Cancer: A Global Perspective. Washington, DC: American Institute for Cancer Research; 1997.

13. Birt DF, Phytochemicals and cancer prevention from epidemiology to mechanism of action, Journal of American Dietetic Assoc, 2006, 106(10), 20-21.

14. Hartwell JL, Plants used against cancer- A survey, Lloy dia, 1969, 32, 247-296.

15. Hartwell JL, Plants used against cancer- A survey, Lloydia, 1969, 32, 153-205

16. Hartwell JL, Plants used against cancer- A survey, Lloy dia, 1969, 32, 78-107.

17. Hartwell JL, Plants used against cancer- A survey, Lloydia, 1970, 33, 288-392.

18. Hartwell JL, Plants used against cancer- A survey, Lloy dia, 1970, 33, 97-194.

19. Hartwell JL, Plants used against cancer- A survey, Lloydia, 1971, 34, 386-425.

20. Hartwell JL, Plants used against cancer- A survey, Lloy dia, 1971, 34, 204-255.

21. Hartwell JL, Plants used against cancer- A survey, Lloydia, 1971, 34, 310-361.

22. Hartwell JL, Plants used against cancer- A survey, Lloydia, 1971, 34, 103-150.

23. Pandey G. Anticancer herbal drugs of India with special reference to Ayurveda. New Delhi: Sri Satguru Publications; 2002. P. 18-121.

24. Kerr JFR, Wyllie AH, Currie AR, Apoptosis: a basic biological phenomenon with wide -ranging implications in tissue kinetics, British Journal of Cancer, 1972, 26, 239-257.

25. Susin SA, Zamzami N, Kroemer G, Mitochondria as regulators of apoptosis doubt no more, Biochem Biophys Acta, 1998, 1366, 151-165.
26. Reed JC, Tomacelli KJ, Drug discovery opportunities from apoptosis research, Curr Opin Biotechnol, 2000, 11, 586592.

27. Diehl JA, Cycling to cancer with cyclin D1, Cancer Biol Ther, 2002, 1(3), 226-231.

28. Mukherjee AK, Basu S, Sarkar N, Ghosh AC, Advances in cancer therapy with plant based natural products, Curr Med Chem, 2001, 8, 1467-1486.

29. Cragg GM, Newmann DJ, Plants as sources of anticancer agents, J Ethnopharmacol, 2005, 100, 72-79.

30. Lee CS, Kim YJ, Han ES, Glycy rrhizin protection against 3morpholinosydnonime induced mitochondrial dysfunction and cell death in lung epithelial cells, Life Sci, 2007, 80(19), 1759-1767.

31. Oh JI, Chun KH, Joo SH, Oh YT, Lee SK, Chemopreventive properties of ethanol extracts of Chinese licorice root induction of apoptosis and G1 cell cycle arrest in MCF-7 human breast cancer cells, Cancer Letters, 2005, 230(2), 228-238.

32. Poli F, Appendino G, Sacchetti G, Ballero M, Maggiano N, Raneletti FO, Antiproliferative effects of daucane esters from ferula communis and ferula arrigonii on human colon cancer cell lines, Phytotherapy Res, 2005, 19(2), 152-157.

33. Shi RX, Ong CN, Shen HM, Protein kinase C inhibition and $\mathrm{x}$-linked inhibition of apoptosis protein degradation contribute to the sensitization effect of luteolin on tumor necrosis factor related apoptosis inducing ligand induced apoptosis in cancer cells, Cancer Res, 2005, 65, 7815-7823.

34. Selvendiran K, Koga H, Ueno T, Yoshida T, Maeyama M, Torimura T, Yano H, Kojiro M, Sata M, Luteolin promotes degradation in signal transducer and activator of transcription 3 in human hepatoma cells: an implication for the antitumor potential of flavonoids, Cancer Res, 2006, 66(9), 4826-4834.

35. Horinaka M, Yoshida T, Shiraishi T, Nakata S, Wakada M, Nakanishi R, Nishino H, Matsui H, Sakai T, Luteolin induces apoptosis via death receptor 5 up regulation in human malignant tumor cells, Oncogene, 2005, 24, 71807189.

36. Chen CY, Liu TZ, Liu YW, Tseng WC, Liu RH, Lu FJ, Lin YS, Kuo S, Chen $\mathrm{CH}$, 6-shagaol (alkanone from ginger) induces apoptotic cell death of human Hepatoma p53 mutant Mahlavu subline via an oxidative stress mediated caspases dependent mechanism, J Agric Food Chem, 2007, 55(3), 948-954.

37. Kim JK, Kim Y, Na KM, Surh YJ, Kim TY, [6]-gingerol prevents UVB induced ROS production and cox-2 expression in vitro and in vivo, Free Radic Res, 2007, 41(5), 603-614.

38. Miyoshi N, Nakamura Y, Ueda Y, Abe M, Ozawa Y, Uchida $\mathrm{K}$, Osawa T, Dietary ginger constituents, galanals A and $\mathrm{B}$, are potent apoptosis inducers in Human T lymphoma Jurkat cells, Cancer Lett, 2003, 199(2), 113-119.

39. Chainy GB, Manna SK, Chaturvedi MM, Aggarwal BB, Anethol blocks both early and late cellular responses tranduced by tumor necrosis factor-kappa B activation,AP-1, JNK, MAPKK and apoptosis, Oncogene, 2000, 19(25), 2943-2950.

40. Weir NM, Selvendiran K, Kutala VK, Tong L, Vishwanath S, Rajaram M, Tridandapani S, Anant S, Kuppusamy P, Curcumin induces G2M arrest and apoptosis in cisplastin resistant human ovarian cancer cells by modulating Akt and p38 MAPK, Cancer Biol Ther, 2007, 6(2), 178-184.

41. Park MJ, Kim EH, Park IC, Lee HC, Woo SH, Lee JY, Curcumin inhibits cell cycle progression of immortalized human umbilical vein endothelial (ECV304) cells by up- 
regulating cdk inhibitor $\mathrm{p} 21 \mathrm{WAF} 1 / \mathrm{CIP} 1, \mathrm{p} 27 \mathrm{KIP} 1$ and $\mathrm{p} 53$, Int J Oncol, 2002, 21(2), 379-383.

42. Choudhuri T, Pal S, Agwarwal ML, Das T, Sa G, Curcumin induces apoptosis in human breast cancer cells through $\mathrm{p} 53$ dependent Bax induction, FEBS Lett, 2002, 512(1-3), 334340.

43. Nonn L, Duong O, Peehl DM, Chemopreventive antiinflammatory activities of curcumin and other phytochemicals mediated by MAP kinase phosphatase in prostrate cells, Carcinogenesis, 2007, 28(6), 1188-1196.

44. Gao X, Deeb D, Jiang H, Liu YB, Dulchavsky SA, Gautam SC, Curcumin differentially sensitizes malignant glioma cells to TRAIL/Apo2L-mediated apoptosis through activation of procaspases and release of cytochrome $\mathrm{C}$ from mitochondria, J Exp Ther Oncol, 2005, 5, 39-48.

45. Shankar S, Srivastava RK, Bax and Bak genes are essential for maximum apoptotic response by curcumin a polyphenolic compound and cancer chemopreventive agent derived from turmeric, Carcinogenesis, 2007, 28(6), 12771286.

46. Devrajan K, Ramachandran R, Santosh K, Involvement of Bax in the regulation of curcumin-induced apoptosis, Ind $\mathrm{J}$ Med Res, 2005, 121, 4-31.

47. Bisht S, Feldmann G, Soni S, Ravi R, Kariker C, Maitra A, Polymeric nano particle encapsulated curcumin (nanocurcumin) a novel strategy for human cancer therapy, J Nanobiotechnology, 2007, 17, 5-22.

48. Kunnumakkara AB, Guha S, Krishanan S, Diagaradjane P, Gelovani J, Aggarwal BB, Curcumin potentiates antitumor activity of gemcitabine in an orthotopic model of pancreatic cancer through suppression of proliferation; angiogenesis and inhibition of nuclear factor kappa $B$ regulated gene products, Cancer Res, 2007, 67(8), 3863-3861.

49. Banerjee S, Panda CK, Das S, Clove (Syzygium aromaticum L.) a potential chemopreventive agent for lung cancer, Carcinogenesis, 2006, 27(8), 1645-1654.

50. Schoene NW, Kelly MA, Polansky MM, Anderson RA, Water soluble polymeric polyphenols from cinnamon inhibit proliferation and alter cell cycle distribution patterns of hematologic tumor cell lines, Cancer Letter, 2005, 230, 134140.

51. Mantena SK, Baliga MS, Katiyar SK, Grape seed proanthocyanidins induce apoptosis and inhibit metastasis of highly metastatic breast carcinoma cells, Carcinogenesis, 2006, 27(8), 1682-1691.

52. Ye X, Krohn RL, Liu W, Joshi SS, Kuszynski CA, McGinn TR, Bagchi M, Preuss HG, Stohs SJ, Bagchi D, The cytotoxic effects of novel IH636 grape seed proanthocy anidin extract on cultured human cancer cells, Mol Cell Biochem, 1999, 196, 99-108.

53. Mittal A, Elmets CA, Katiyar SK, Dietary feeding of proanthocyanidins from grape seeds prevents photocarcinogenesis in SKH-1 hairless mice relationship to decreased fat and lipid peroxidationm, Carcinogenesis, 2003, 24, 1379-1388.

54. Vayalil PK, Mittal A, Katiyar SK, Proanthocyanidins from grape seeds inhibit expression of matrix metalloproteinases in human prostrate carcinoma cells which is associated with the inhibition of activation of MAPK and NF kappa B, Carcinogenesis, 2004, 25, 987-995.

55. Chung WC, Lin JP, Yang JS, Chou ST, Chen SC, Lin YT, Lin HL, Chung JG, Capsaicin induced cell cycle arrest and apoptosis in human esophagus epidermoid carcinoma CE 81 T/VGH cells through the elevation of intracellular ROS and $\mathrm{Ca}^{+2}$ production and caspases- 3 activation, Mutation Research, Fundamental and Molecular Mechanism of Mutagenesis, 2006, 601(1/2), 71-82.
56. Sanchez AM, Sanchez MG, Malagarie-Cazenave S, Olea N, Diaz-Laviada I, Induction of apoptosis in prostate tumor PC3 cells and inhibition of xenograft prostate tumor growth by the vanilloid capsaicin, Apoptosis, 2006, 11, 89-99.

57. Mori A, Lehmann S, O'Kelly J, Kumagai T, Desmond JC, Pervan M, McBride WH, Kizaki M, Koeffler HP, Capsaicin, a component of red peppers, inhibits the growth of androgen independent, p53 mutant prostate cancer cells, Cancer Res, 2006, 66, 3222-3229.

58. Trincheri NF, Nicotra G, Follo C, Castino R, Isidoro C, Resveratrol induces cell death in colorectal cancer cells by a novel pathway involving lysosomal cathepsin D, Carcinogenesis, 2007, 28(5), 922-931.

59. Fulda S, Debatin KM, Sensitization for Tumor Necrosis Factor-Related Apoptosis-Inducing Ligand-Induced Apoptosis by the Chemopreventive Agent Resveratrol, Cancer Research, 2004, 64, 337-346.

60. Ahmad KA, Clement MV, Hanif IM, Pervaiz S, Resveratrol inhibits drug induced apoptosis in human leukemia cells by creating an intracellular milieu non-permissive for death execution, Cancer Res, 2004, 64, 1452-1459.

61. Fulda S, Debatin KM, Sensitization for TNF related apoptosis inducing ligand induced apoptosis by chemopreventive agent resveratrol, Cancer Res, 2004, 64, 337-346.

62. Castello L, Tessitore L, Resveratrol inhibits cell cycle progression in U937 cells, Oncol Rep, 2005, 13, 133-137.

63. Hsieh $\mathrm{TC}$, Wang $\mathrm{Z}$, Hamby $\mathrm{CV}$, Wu JM, Inhibition of melanoma cell proliferation by resveratrol is correlated with up regulation of quinone reductase 2 and p53, Biochem Biophys Res Commun, 2005, 334(1), 223-230.

64. Ahmad N, Adhami VM, Afaq F, Feyes DK, Mukhtar H, Resveratrol causes WAF-1/p21-mediated G (1)-phase arrest of cell cycle and induction of apoptosis in human epidermoid carcinoma A431 cells, Clin Cancer Res, 2001, 7(5), 1466-1473.

65. Liang YC, Tsai SH, Chen I, Lin-Shiau SY, Lin JK, Resveratrol induced G2 arrest through the inhibition of CDK7 and p34CDC2 kinases in colon carcinoma HT29 cells, Biochem Pharmacol, 2003, 65(7), 1053-1060.

66. Wolter F, Akoglu B, Clausnitzer A, Stein J, Down regulation of cyclin D1/Cdk4 complex occurs during resveratrol induced cell cycle arrest in colon cancer cell lines, J Nutr, 2001, 131(8), 2197-2203.

67. Opiari AW, Tan LJ, Boitano AE, Sorenson DR, Aurora A, Liv JR, Resveratrol induced autophagocytosis in ovarian cancer cells, Cancer Res, 2004, 64, 696-703.

68. Riles WL, Erickson J, Nayyer S, Atten MJ, Attar BM, Holian D, Resveratrol engages selective apoptotic signals in gastric adeno carcinoma cells, World $\mathbf{J}$ of Gasteroenterology, 2006, 12(35), 5628-5634.

69. Luo Q, Pang YQ, Yang ML, Yan J, Wang LH, Gi XY, Effects of grape juice on proliferation and apoptosis of human prostate carcinoma PC-3 cells, Acta Nutrimenta Sinica, 2006, 28(5), 418-422.

70. Saleem M, Kweon MH, Yun JM, Adhami VM, Khan N, Syed DN, Mukhtar H, A novel dietary triterpene lupeol induces fas-mediated apoptotic death of androgen-sensitive prostate cancer cells and inhibits tumor growth in xenograft model, Cancer Res, 2005, 65, 11203-11213.

71. Khan N, Hadi N, Afaq F, Syed DN, Kweon MH, Mukhtar $\mathrm{H}$, Pomegranate fruit extract inhibits prosurvival pathways in human A549 lung carcinoma cells and tumor growth in athy mic nude mice, Carcinogenesis, 2007, 28(1), 163-173.

72. Khan N, Afaq F, Kweon MH, Kim K, Mukhtar H, Oral consumption of pomegranate fruit extract inhibits growth 
and progression of primary lung tumor in mice, Cancer Research, 2007, 67(7), 3475-3482.

73. Malik A, Afaq F, Sarfaraz S, Adhami VM, Syed DN, Mukhtar H, Pomegranate fruit juice for chemoprevention and chemotherapy of prostate cancer, Proc Natl Acad Sci USA, 2005, 102, 14813-14818.

74. Afaq F, Syed DN, Malik A, Hadi N, Sarfaraz S, Kweon MH, Khan N, Zaid MA, Mukhtar H, Delphinidin, an anthocy anidin in pigmented fruits and vegetables, protects human $\mathrm{HaCaT}$ keratinocytes and mouse skin against UVBmediated oxidative stress and apoptosis, J Invest Dermatol, 2007, 127(1), 222-232.

75. Ferguson PJ, Kurowska EM, Freeman DJ, Chambers AF, Koropatnick J, In vivo inhibition of growth of human tumor lines by flavonoid fractions from cranberry extract, Nutrition and Cancer, 2006, 56(1), 86-94.

76. Grenado-Serrano AB, Martin MA, Bravo L, Goya L, Ramos $\mathrm{S}$, Quercetin induces apoptosis via caspases activation regulation of Bcl-2 and inhibition of PI-3-kinase/Akt and ERK pathways in a human Hepatoma cell line, J Nutr, 2006, 136, 2715-2721.

77. Seeram NP, Adams LS, Zhang YJ, Lee R, Sand D, Scheuller HS, Heber D, Blackberry, black raspberry, blue berry, can berry, red raspberry, and strawberry, extracts inhibit growth and stimulate apoptosis of human cancer cells in vitro, J. Agric Food Chem, 2006, 54(25), 9329-9339.

78. Fujii T, Ikami T, Xu JW, Ikeda K, Prune extracts suppress the proliferation and induces the apoptosis of human colon carcinoma Caco-2, J Nutr Science and Vitaminology, 2006, 52(5), 389-391.

79. Chen T, Rose ME, Hwang H, Nines RG, Stoner GD, Black raspberries inhibit $\mathrm{N}$-nitroso methyl benzylamine induced angiogenesis in rat esophagus parallel to the suppression of cox-2 and iNOS, Carcinogenesis, 2006, 27(11), 2301-2307.

80. Hecht SS, Huang C, Stoner GD, Li J, Kenney PMJ, Sturla SJ, Carmella SG, Identification of cyaniding glycosides as constituents of freeze dried black raspberries which inhibit anti benzo \{a\} pyrene-7, 8-diol 9,10 epoxide induced NF kappa B and AP-1 activity, Carcinogenesis, 2006, 27(8), 1617-1626.

81. Kresty LA, Morse MA, Morgan C, Carlton PS, Lu J, Gupta A, Blackwood M, Stoner GD, Chemoprevention of oesophageal tumorigenesis by dietary administration of ly ophilized black raspberries, Cancer Res, 2001, 61, 61126119.

82. Casto BC, Kresty LA, Kraly CL, Pearl DK, Knobloch TJ, Shut HA, Stoner GD, Mallery SR, Weghorst CM, Chemoprevention of oral cancer by black raspberries Anticancer Res, 2002, 22, 4005-4015.

83. Harris GK, Gupta A, Nines RG, Kresty LA, Habib SG, Frankel WL, LaPerle K, Gallaher DD, Schwartz SJ, Stoner GD, Effect of lyophilized black raspberries on azoxymethane induced colon cancer and 8-hydroxy-2'deoxyguanosine levels in the Fisher 344 rat, Nutr Cancer, 2001, 40, 125-133.

84. Xiao D, Zeng Y, Choi S, Lew KL, Nelson JB, Singh SV, Caspases dependent apoptosis induction by phenthyl isothiocyanate, a cruciferous vegetable derived cancer chemopreventive agent is mediated by Bak and Bax, Clini Cancer Res, 2005, 11(7), 2670-2679.

85. Zhao H, Lin J, Grossman HB, Hernandez LM, Dinney CP, $\mathrm{Wu} \mathrm{X}$, Dietary isothionates, GSTM1, GSTT1, NAT 2, poly morphism and bladder cancer risk, Int J Cancer, 2007, 120, 2208-2213.

86. Yasunari T, Michael A, Aggarwal BB, Indole-3-carbinol suppresses $\mathrm{NF}-\kappa \mathrm{B}$ and $\mathrm{I} \approx \mathrm{B} \alpha$ kinase activation, causing inhibition of expression of NF-kB-regulated antiapoptotic and metastatic gene products and enhancement of apoptosis in my eloid and leukemia cells, Blood, 2005, 106, 641 - 649.

87. Jakuvikova J, Bao Y, Sedlak J, Isothiocy anates induce cell cycle arrest apoptosis and mitochondrial potential depolarization in HL-60 and multidrug resistant cell lines, Anticancer Res, 2005, 25(5), 3375-3386.

88. Zhang R, Loganathan S, Humphreys I, Srivastava SK, Benzyl isothiocy anate induced DNA damage causes G2/M cell cycle arrest and apoptosis in human pancreatic cancer cells, J Nutr, 2006, 136, 2728-2734.

89. Arditti FD, Rabinkov A, Miron T, Reisner Y, Berrebi A, Wilchek M, Mirelman D, Apoptotic killing of B-chronic lymphocytic leukemia tumor cells by allicin generated in situ using a rituximab-alliinase conju gate, $\mathrm{Mol}$ Cancer Ther, 2005, 4(2), 325-331.

90. Herman-Antosiewicz A, Singh SV, Signal transduction pathways leading to cell cycle arrest and apoptosis induction in cancer cells by Allium vegetable-derived organosulfur compounds: a review, Mutat Res, 2004, 555(1-2), 121-131.

91. Karmakar S, Banik NL, Patel SJ, Ray SK, Garlic compounds induced calpin and intrinsic caspase cascade for apoptosis in human malignant neuroblastoma SH-SY5Y cells, Apoptosis, 2007, 12(4), 671-684.

92. Xia L, Ng TB, Isolation of alliumin a novel protein with antimicrobial and antiproliferative activities from multiple cloved garlic bulbs, Peptides, 2005, 26(2), 177-183.

93. Saller R, Melzer J, Reichling J, Brignoli R, Meier R, An updated systematic review of the pharmacology of sily marin, Forsch Komplementarmed, 2007, 14(2), 70-80.

94. Gu M, Dhanalakshmi S, Singh RP, Agarwal R, Dietary feeding of silibinin prevents early biomarkers of UVB radiation-induced carcinogenesis in SKH-1 hairless mouse epidermis, Cancer Epidemiol Biomarkers Prev, 2005, 14(5), 1344-1349.

95. Zhong X, Zhu Y, Lu Q, Zhang J, Ge Z, Zheng S, Silymarin causes caspases activation and apoptosis in K562 leukemia cells through inactivation of Akt pathway, Toxicology, 2006, 227, 211-216.

96. Tyagi AK, Singh RP, Aggarwal C, Aggarwal A, Silibinin activates p53 caspase -2 pathway and causes caspases mediated cleavage of cip $1 / \mathrm{p} 21$ in apoptosis induction in bladder transitional cell papiloma RT4 cells. Evidence for a regulatory loop between p53 and caspases-2, Carcinogenesis, 2006, 27(11), 2269-2280.

97. Tyagi AK, Singh RP, Aggarwal C, Chan DC, Aggarwal R, Silibinin strongly synergises human prostate carcinoma DU145 cells to doxorubicin-induced growth inhibition, G2M arrest and apoptosis, Clin Cancer Res, 2002, 8(11), 3512-3519.

98. Flaig WT, Su LJ, Harrison G, Aggarwal R, Glode ML, Silibinin synergizes with mitoxantrone to inhibit cell grow th and induce apoptosis in human prostate cancer cells, Int $\mathbf{J}$ Cancer, 2007, 120, 2028-2033.

99. Vargo MA, Voss OH, Poustka F, Cardounel AJ, Grotewold E, Doseff AI, Apigenin-induced-apoptosis is mediated by the activation of PKC delta and caspases in leukemia cells, Biochem Pharmacol, 2006, 72(6), 681-692.

100. Shukla S, Mishra A, Fu P, MacLennan GT, Resnick MI, Gupta S, Up-regulation of insulin-like growth factor binding protein-3 by apigenin leads to growth inhibition and apoptosis of 22Rv1 xenograft in athy mic nude mice, FASEB J, 2005, 19(14), 2042-2044.

101. Takagaki N, Sowa Y, Oki T, Nakanishi R, Yogosawa S, Sakai T, Apigenin induces cell cycle arrest and p21/WAF1 expression in a p53-independent pathway, Int J Oncol, 2005, 26(1), 185-189. 
102. McCabe MJ, Orrenius S, Genistein induces apoptosis in immature human thy mocytes by inhibiting topoisomerase-II, Biochem Biophys Res Commun, 1993, 194, 944-950.

103. Su SJ, Chow NH, Kung ML, Hung TC, Chang KL, Effects of soy isoflavones on apoptosis induction and G2-M arrest in human hepatoma cells involvement of caspase-3 activation $\mathrm{Bcl}-2$ and $\mathrm{Bcl}-\mathrm{XL}$ down regulation and $\mathrm{Cdc} 2$ kinase activity, Nutr Cancer, 2003, 45, 113-123.

104. Raffoul JJ, Banerjee S, Che M, Knoll O, Sarkar FH, Hillman $\mathrm{GG}$, Soy isoflavonoids enhance radiotherapy in a metastatic prostate cancer model, Int J Cancer, 2007, 120, 2491-2498.

105. Heath E, Sahin K, Seren S, Kucuk D, Lycopene prospects for chemoprevention and treatment of prostate cancer, Nutritional Abstracts \& Reviews, 2007, 77(2), 1-9.

106. Liu C, Russell RM, Wang XD, Lycopene supplementation prevents smoke-induced changes in p53, p53 phosphorylation, cell proliferation, and apoptosis in the gastric mucosa of ferrets, J Nutr, 2006, 136(1), 106-111.

107. Hantz HL, Young LF, Martin KR, Phy siologically attainable concentrations of lycopene induce mitochondrial apoptosis in LNCaP human prostate cancer cells, Exp Biol Med, 2005, 230, 171-179.

108. Palozza P, Can beta-carotene regulates cell growth by a redox mechanism? An answer from cultured cells, Biochim Biophys Acta, 2005, 1740, 216-221.

109. Palozza P, Serini S, Torsello A, Di Nicuolo F, Maggiano N, Mechanism of Activation of Caspase Cascade during $\beta$ Carotene-Induced Apoptosis in Human Tumor Cells, Nutr Cancer, 2003, 47, 76-87.

110. Kumar A, Dhawan S, Aggarwal B B, Emodin (3-methy 1-1, 6, 8-trihy droxy anthraquinone) inhibits TNF- induced NFkapp $\mathrm{aB}$ activation, $1 \mathrm{kappaB}$ degradation, and expression of cell surface adhesion proteins in human vascular endothelial cells, Oncogene, 1998, 17(7), 913-918.

111. Kandasamy K, Gunasekaran P, Ramamurthy N, Govindasamy S, Anticancer activity of Ocimum sanctum, Pharmaceutical Biology, 1999, 37(4), 285-290.

112. Nayak V, Devi PU, Protection of mouse bone marrow against radiation induced chromosome damage and stem cell death by the Ocimum flavonoids orientin and vicenin, Radiat Res, 2005, 163(2), 165-171.

113. Kundu T, Dey S, Roy M, Siddiqi M, Bhattachary a RK, Induction of apoptosis in human leukemia cells by black tea and its polyphenol theaflavin, Cancer Letters, 2005, 230, 111-121.

114. Siddiqui IA, Zaman N, Aziz MH, Reagen Shaw SR,Sami S, Adhami VM, Raisuddin S, Ahmad N, Mukhtar H, Inhibition of CWR22R $\nu_{1}$ tumor growth and PSA secretion in athymic nude mice by green and black teas, Carcinogenesis, 2006, 27, 833-839.

115. Bhattacharyy a A, Lahiry L, Mandal D, Sa G, Das T, Black tea induces tumor cell apoptosis by Bax translocation, loss in mitochondrial transmembrane potential, cytochrome c release and caspase activation, Int J Cancer, 2005, 117(2), 308-315.

116. Yang C, Landan J, Huang M, Newmark H, Inhibition of carcinogenesis by dietary polyphenolic compounds, Ann Rev Nutr, 2000, 20, 485-505.

117. Cao Y, Cao R, Angiogenesis inhibited by drinking tea, Nature, 1999, 398, 381

118. Qanungo S, Das M, Haldar S, Basu A, Epigallocatechin-3gallate induces mitochondrial membrane depolarization and caspase dependent apoptosis in pancreatic cancer cells, Carcinogenesis, 2005, 26, 958-967.

119. Ko SY, Chang KW, Liu SC, Hsu HC, Liu TY, The repressive effect of green tea ingredients on amyloid precursor protein (APP) expression in oral carcinoma cells in vitro and in vivo, Cancer Letters, 2007, 245, 81-89.

120. Babich H, Krupka ME, Nissim HA, Zuckerbrann HL, Differential invitro cytotoxicity of (-) epicatechin gallate to cancer and normal cells from human oral cavity, Toxicol. In Vitro, 2005, 19, 231-242.

121. Roy M, Chakraborty S, Dey S, Bhattachary a RK, Siddiqi M, Anticlastogenic, antigenotoxic and apoptotic activity of epigallocatechin gallate a green tea polyphenol, Mutat.Res, 2003, 523-524, 33-41.

122. Stuart EC, Scandlyn MJ, Rosengren RT, Role of epigallocatechin gallate in treatment of breast and prostate cancer, Life Science, 2006, 79(25), 2329-2336.

123. Brusselmans K, De Schrijver E, Heyns W, Verhoeven G, Swinnen JV, Epigallocatechin-3-gallate is a potent natural inhibitor of fatty acid synthase in intact cells and selectively induces apoptosis in prostate cancer cells, Int $\mathrm{J}$ Cancer, 2003, 106, 856-862.

124. Hastak K, Agarwal MK, Mukhtar H, Agarwal ML, Ablation of either p21 or Bax prevents p53-dependent apoptosis induced by green tea polyphenol epigallocatechin-3-gallate, FASEB J, 2005, 19(7), 789-791.

125. Nishikawa T, Nakajima T, Moriguchi M, Sekoguchi MJ, Ishii M, Takashima H, Katagishi T, Kimura H, Minami M, A green tea polyphenol, epigalocatechin-3-gallate, induces apoptosis of human hepatocellular carcinoma, possibly through inhibition of Bcl-2 family proteins, J Hepatol, 2006, 44(6), 1074-1082.

126. Ahmad N, Feyes DK, Nieminen AL, Agarwal R, Mukhtar H, Green tea constituent, J Natl Cancer Inst, 1997, 89, 18811886.

127. Naghma Khan, Farrukh Afaq, Mohammad Saleem, Nihal Ahmad, Hasan Mukhtar, Targeting Multiple Signaling Pathways by Green Tea Polyphenol (-)-Epigallocatechin-3Gallate, Cancer Research, 2006, 66, 2500-2505.

128. Nihal M, Ahmad N, Mukhtar H, Wood GS, Antiproliferative and pro-apoptotic effects of (-)epigallocatechin-3-gallate on human melanoma: Possible implications for the chemoprevention of melanoma, Int $\mathbf{J}$ Cancer, 2005, 114, 513-521.

129. Sartippour MR, Pietras R, Marquez-Garban DC, Chen HW, Heber D, Henning SM, Sartippour G, Zhang L, Lu M, Weinberg O, Rao JY, Brooks MN, The combination of green tea and tamoxifen is effective against breast cancer, Carcinogenesis, 2006, 27(12), 2424-2433.

130. Hong J, Sang S, Park HJ, Kwon SJ, Suh N, Huang MT, Ho CT, Yang CS, Modulation of arachidonic acid metabolism and NO synthesis by garcinol and its derivatives, Carcinogenesis, 2006, 27(2), 278-286.

131. Pan MH, Chang WL, Lin-Shian SY, Ho CT, Lin JK, Induction of apoptosis by garcinol and curcumin through cytochrome $\mathrm{C}$ release and activation of caspases in human leukemia HL-60 cells, J Agr Food Chem, 2001, 49, 14641474.

132. Lu YP, Lou YR, Xie JG, Peng QY, Zhou S, Lin Y, Shih WJ, Conney AH, Caffeine and caffeine sodium benzoate have a sunscreen effect enhance UVB induced apoptosis and inhibit UVB induced skin carcinogenesis in SKH-1 mice, Carcinogenesis, 2007, 28(1), 199-206.

133. Huang MT, Xie JG, Wang ZY, Ho CT, Lou YR, Wang CX, Hard GC, Conney AH, Effects of tea and decaffeinated tea and caffeine on UVB induced skin carcinogenesis in SKH-1 mice demonstration of caffeine as a biologically important constituent of tea, Cancer Res, 1997, 57, 2623-2629.

134. Lou YR, Lu YP, Xie JG, Huang MT, Conney AH, Effects of oral administration tea and decaffeinated tea and caffeine on the formation and growth of tumors in high-risk SKH-1 
mice previously treated with UVB light, Nutr. Cancer, 1999, 33, 146-153.

135. Lu YP, Lou YR, Li XH, Xie JG, Brash D, Huang MT, Conney AH, Stimulatory effects of oral administration tea and decaffeinated tea and caffeine on UVB light induced increase in epidermal wild type p53, p21 (WAF1/C1P1) and apoptotic sunburn cells in SKH-1 mice, Cancer Res, 2000, 60, 4785-4791.

136.Lu YP, Lou YR, Li XH, Xie JG, Lin Y, Weichung JS, Conney AH, Stimulatory effect of topical applications of caffeine on UVB induced apoptosis in mouse skin, Oncol Res, 2002, 13, 61-70.

137. Ragone FD, Cucciolla V, Borriello A, Pietra VD, Pontoni G, Racioppi L, Manna C, Galetti P, Zappia V, Hydrotyrosol a natural molecule occurring in olive oil induces cytochrome C dependent apoptosis, Biochem Biophys Res Communi, 2000, 278, 733-739.

138. Fabiani R, Barteolomeo AD, Rosignoli P, Servili M, Selvagini R, Montedord GF, Saverio CD, Morozzi G, Virgin olive oil phenols inhibit proliferation of human promyelocytic leukemia cells by inducing apoptosis and differentiation, J Nutr, 2006, 136, 614-619.

139. Fabiani R, Barteolomeo AD, Rosignoli P, Servili M, Montedord GF, Saverio CD, Morozzi G, Cancer chemoprevention by hydroxy tyrosol from virgin olive oil through G1 cell cycle arrest and apoptosis, Eur J Cancer Prev, 2002, 11, 351-358.

140. Juan ME, Wenzel U, Ruiz-Gutierrez V, Daniel H, Planas $\mathrm{JM}$, Olive fruit extracts inhibit proliferation and induce apoptosis in HT-29 human colon cancer cells, J Nutr, 2006, 136, 2553-2557.

141. Watabe M, Hishikawa K, Takay anagi A, Shimizu N, Nakaki T, Caffeic Acid Phenethyl Ester Induces Apoptosis by Inhibition of $\mathrm{NKKB}$ and Activation of Fas in Human Breast Cancer MCF-7 Cells, J Biol Chem, 2004, 279(7), 60176026. 